\title{
The Effect of Trade Policy on The Position of Indonesian Coffee Market among The Major Importing Countries
}

\author{
Sevi Oktafiana Fortunika ${ }^{1,{ }^{*}}$, Harianto $^{1}$, Suharno ${ }^{1}$ \\ 1 Departement of Agribusiness, Faculty of Economics and Management, Institut Pertanian Bogor, \\ Raya Darmaga Street, IPB Darmaga Campus, Bogor 16680, West Java, Indonesia
}

\begin{abstract}
Indonesia is the largest coffee producer in the world after Brazil, Vietnam and Colombia, but it was confronted with market problems. This paper, therefore, analysed the demand system as the position market for Indonesian coffee, either green bean or roasted coffee in the main importing countries such as Germany, Japan and The United States. The linear Approximate Almost Ideal Demand System (LA/AIDS) model was used to analyse the position of Indonesian coffee and its competitors. Time series data from 1996 to 2017 were obtained for the analysis. Empirical results indicated that most of the slope coefficients were statistically significant and in accordance with microeconomic theory. The variables of trade policy effected the Indonesian coffee trade. Indonesian green bean was found to be elastic in Germany, Japan, and The United States. Then, Indonesian roasted coffee was found to be inelastic in Japan. Indonesian green bean was a luxury good only in Germany, but Indonesian roasted coffee was an inferior good in Germany and The United States. Both Indonesian green bean and roasted coffee were a necessity in Japan. Almost Indonesian coffee substitute for Brazilian coffee and Colombian coffee, and complementary with Vietnamese coffee as its competitor.
\end{abstract}

\section{Introduction}

Coffee is consumed by most industrialized countries, such as The United States, European Union and Japan, but it is grown and exported by almost developing countries, like Indonesia, Vietnam and Brazil. Coffee is the second major traded commodity in the world after oil, so that it plays a vital role in the balance of trade between developed and developing countries.

Indonesia is one of the largest coffee producers in the world, which is the fourth number of production after Brazil, Vietnam and Colombia, reaching 654 thousand tons in 2017 or equal to 6.84 percent of world coffee production which was showed by Figure 1. Indonesia Eximbank Institute and UNIED mention that Indonesia has a positive growth with a percentage of 0.12 percent during 2014-2017. The growth experienced positive results in

\footnotetext{
* Corresponding author: sevioktafianafortunika@gmail.com
} 
2015 (15.4 percent), but in 2016 occurred slowing growth of -8.33 percent and then slowing dprice in 2017 amounting to -5.13 percent. [1]

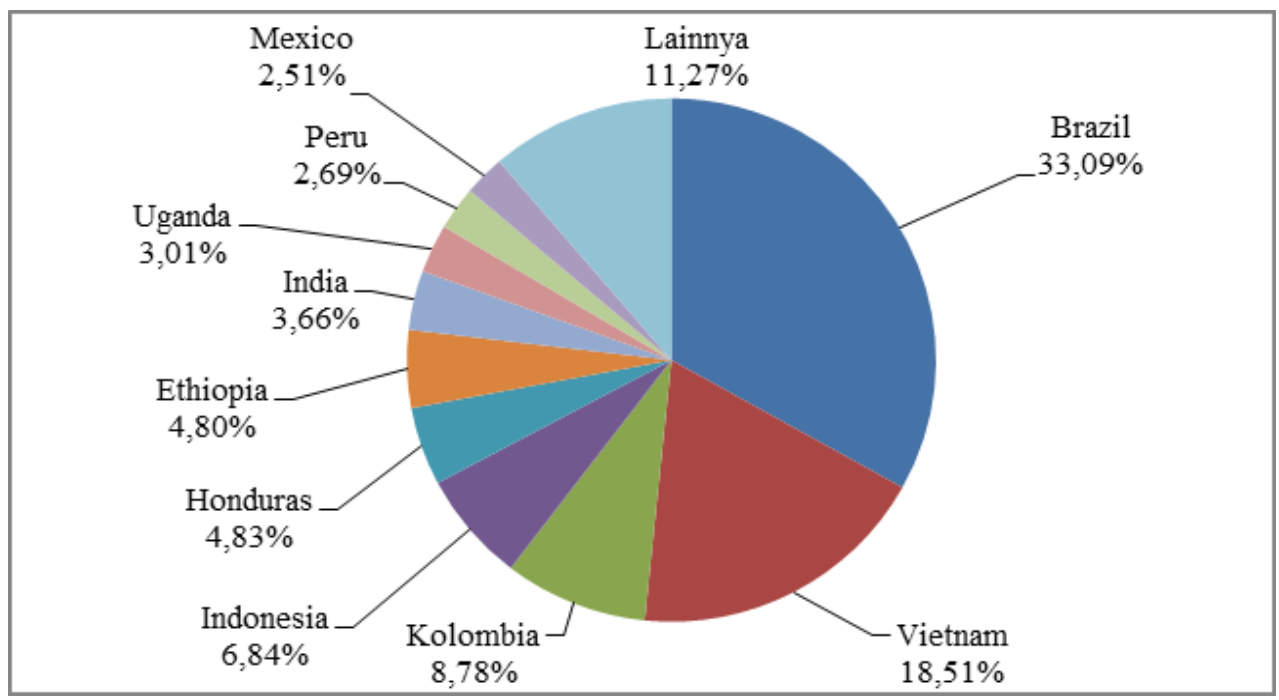

Fig. 1. Proportion of the largest coffee producers in the world in 2017 Source : trademap.org

Indonesia's abundant coffee production making Indonesian coffee exports spread to many countries in the world. This shows that many interested people from abroad want to consume Indonesian coffee. Based on International Trade Statistic Database of Indonesian coffee export from 1996 to 2019, the biggest importer of Indonesian coffee in the world is Europe, followed by Asia and The United States. There were 17 percent of Indonesia's total coffee exports exported to The United States, 29 percent exported to Asia and 34 percent exported to Europe. Thus, it can be seen that the value of Indonesian coffee exports is very large for the three continents.

However, the market share of Indonesian coffee is not proportional to the size of Indonesia's coffee exports. In the same year, the market share of Indonesian coffee in the United States was only 3.8 percent, even in Europe only 1 percent. Furthemore, the market share of Indonesian coffee in the Japan was only 9.9 percent for green bean and 2.2 percent for roasted coffee. When compared with the total world coffee exports, Indonesia is only able to play an role of approximately 6 percent, where the number is still very little to see Indonesia has an extraordinary comparative advantage that other countries in the world do not have.

The price of Indonesia's coffee exports also cannot compete with the other largest export countries such as Brazil and Colombia, as shown in Figure 2. There is a large gap between prices in developed countries and prices in developing countries including Indonesia and Vietnam. Figure 2 showed that export prices in developed countries such as Colombia and Brazil take the lead above, while the prices of Indonesian and Vietnamese coffee exports are far below. 


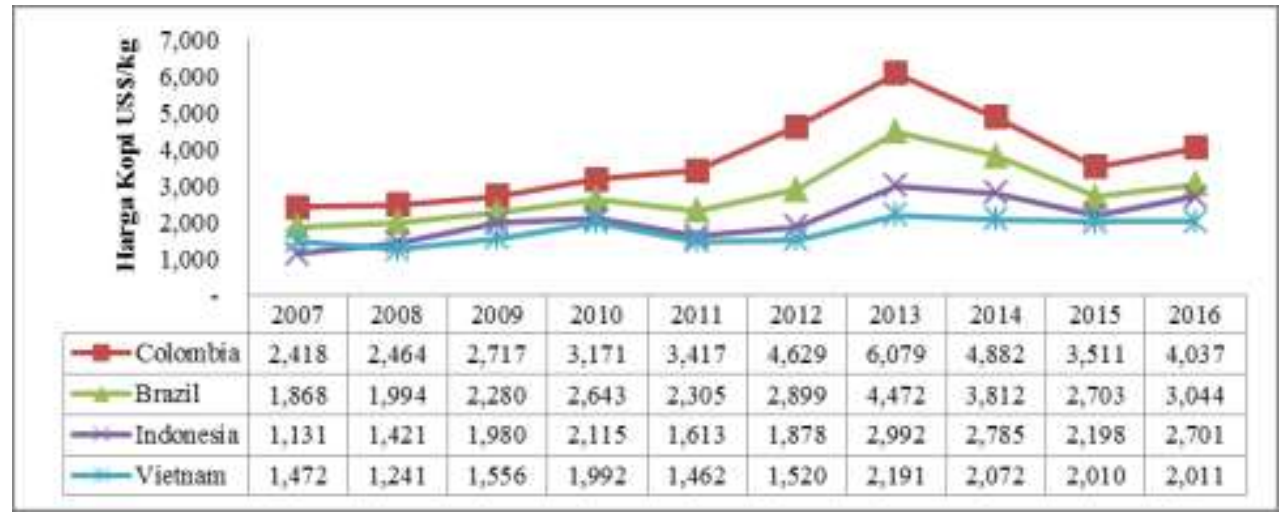

Fig. 2. Coffee export prices in the main exporter countries, 2007-2016 Resource: UN Comtrade, 2019 (processed)

Ministry of Agriculture mention that coffee has an important role in supporting the improvement of the Indonesian economy, where 95 percent of the total coffee plantations in Indonesia are farmers in rural areas. Based on land ownership status, smallholder plantations are still the main dominance in Indonesia. In recent years, coffee production has continued to increase in direct proportion to the increase in ownership status of smallholder plantations [2]. So that, if coffee export of Indonesia increase, the smallholders economy will increase too.

The optimistic to increasing coffee export can be seen from increasing coffee demand in International markets. International Coffee Organization (ICO) reported that the world coffee market tends to increase year by year. World consumption was 169.113 million bags in 2018-2019, an increase of 4.6 percent compared to 2017-2018 and 6.5 percent compared to 2016-2017. Those increasing coffee demand was rise either domestic consumption in exporting countries or in importing countries [3].

However, penetrating the international market with the desired type and price is not easy without a hitch. Not only tariff barriers, but non-tariff barriers such as quality problems and coffee quality standards are also one of the factors that hampered Indonesian exports. Talking about quality standards is inseparable from the competitiveness of commodities, with quality control, several interests will be fulfilled including the interests of safety, security, public health and preservation of environmental functions, all of which are expected outputs from the application of Non-Tariff Measures ( NTM).

According to the study of Purnamasari et al. (2014), Indonesia as the fourth largest coffee exporter in the world does not yet have a competitive advantage compared to other major coffee exporting countries [4]. Besides that limitation, there were some policies created by government to increasing coffee trade. Based on the National Long Term Development Plan (RPJPN) 2015-2019, the government has a target of increasing the export volume of Indonesian coffee beans by 24.3 percent or 462,497 tons in 2025 [5]. In addition to the export target, the government also targets an increase in per capita consumption of $1.5 \mathrm{~kg}$ per year in 2019 which is listed in the National Industrial Development Master Plan (RIPIN) [6]

Therefore, there is a need for further studies on the demand system of Indonesian coffee either green bean or roasted coffee which is entering tariff and non-tariff policies as independent variables. The formulation of the problem in this study is what the factors affect Indonesian coffee exports and how the market position of Indonesian coffee in Germany, Japan, and The United States as the main importing countries among Brazil, Colombia and Vietnam as the major coffee exporter. 


\section{Research Method}

This study discussed the demand for Indonesian coffee exports in the major destination markets (Germany, Japan and The United States) which have the tariffs and non tariff measures. This research was limited to the analysis of competition between Indonesia and the other three main coffee exporting countries, such as Brazil, Colombia, and Vietnam. The data used in this study was data on green bean imports in coffee importing countries with HS 090111 (not roasted, decaffeinated) and roasted coffee with HS 090121 (roasted, decaffeinated).

The types of data used in this study are primary data and secondary data. Primary data is obtained from remote interviews with coffee exporters, coffee experts and relevant associations related to Indonesian coffee exports. Secondary data is obtained from several sources, as shown in Table 1. This study uses monthly time series data for 22 years, from 1996 to 2017.

Table 1. Resources of Secondary Data

\begin{tabular}{|c|c|}
\hline Type of Data & Resources \\
\hline Value and price of coffee export & UN COMTRADE [7] \\
\hline Exchange rates and gross domestic product & WorldBank [8] \\
\hline Import tariffs & ITC (International Trade Center) [9] \\
\hline $\begin{array}{c}\text { Non-tariff measures } \\
\text { (Sanitary \& Phytosanitary, and Technical Barier to Trade) }\end{array}$ & World Trade Organization (WTO) [10] \\
\hline
\end{tabular}

This paper which examined the position of Indonesian coffee among Brazil, Colombia and Vietnam in the main targeting market after trade policies applied focussed on the impact of prices and expenditure shares. The Linear Approximate Almost Ideal Demand System (LA/AIDS) using SUR (Seemingly Unrelated Regression) was the method of the research. This method and variables were based on combination by many researches.

Over time, various AIDS models have been developed such as nonlinear models, linear AIDS, AIDS inversions, AIDS dynamics [11] [12], and AIDS quadratic [13]. In addition, there were other macro-scale studies [14-16] which used a linear approximation of the AIDS model (LA/AIDS). LA/AIDS is often used in AIDS because it makes equations more linear so that they are easy to estimate.

In general there are two AIDS models, namely static models and dynamic models [17]. Static model is a model that analyses the model of long-term balance preferences, namely in other words consumer behavior or respondents are considered to be in a long-term balance or are static. In reality the opposite happens, where consumers can be influenced by several factors that shape different consumer behavior. In addition, the static AIDS model also cannot accommodate the dynamics that occur in the short term. Therefore, a dynamic AIDS model emerged based on the development of an econometric model through error correction techniques proposed by Engle and Grenger [18]. This research applied the AIDS model dynamically and was done by using time series data (equation 1).

$$
\begin{aligned}
& \mathrm{W}_{\mathrm{i}}=\alpha_{i}+\sum_{\left.{ }_{\mathrm{j}=1)}\right)} \gamma_{i j} \ln \mathrm{P}_{\mathrm{j}}+\beta_{i} \ln \left(\mathrm{x} /\left(\mathrm{p}^{*}\right)\right)+\theta_{i} \operatorname{lnER}+\lambda_{i} \operatorname{lnGDP}+\sigma_{i} \mathrm{Tf}+£_{i} \mathrm{SPS}+\varphi_{i} \mathrm{TBT}+\mathrm{e} \\
& \mathrm{wb}=\alpha_{i}+\sum \mathrm{n}_{(\mathrm{j}=1)} \gamma_{\mathrm{ij}} \ln \mathrm{P}_{\mathrm{j}}+\beta_{i} \ln \left(\mathrm{x} /\left(\mathrm{p}^{*}\right)\right)+\theta_{i} \operatorname{lnER}+\lambda_{i} \operatorname{lnGDP}+\sigma_{i} \mathrm{Tf}+£_{i} \mathrm{SPS}+\varphi_{i} \mathrm{TBT}+\mathrm{e} \\
& \mathrm{w}_{\mathrm{c}}=\alpha_{i}+\sum \mathrm{n}_{(\mathrm{j}=1)} \gamma_{\mathrm{ij}} \ln \mathrm{P}_{\mathrm{j}}+\beta_{i} \ln \left(\mathrm{x} /\left(\mathrm{p}^{*}\right)\right)+\theta_{i} \operatorname{lnER}+\lambda_{i} \operatorname{lnGDP}+\sigma_{i} \mathrm{Tf}+£_{i} \mathrm{SPS}+\varphi_{i} \mathrm{TBT}+\mathrm{e} \\
& \mathrm{W}_{\mathrm{v}}=\alpha_{i}+\sum^{\mathrm{n}_{\mathrm{j}=1)}} \gamma_{\mathrm{ij}} \ln \mathrm{P}_{\mathrm{j}}+\beta_{i} \ln \left(\mathrm{x} /\left(\mathrm{p}^{*}\right)\right)+\theta_{i} \ln \mathrm{RR}+\lambda_{i} \operatorname{lnGDP}+\sigma_{i} \mathrm{Tf}+£_{i} \mathrm{SPS}+\varphi_{i} \mathrm{TBT}+\mathrm{e}
\end{aligned}
$$




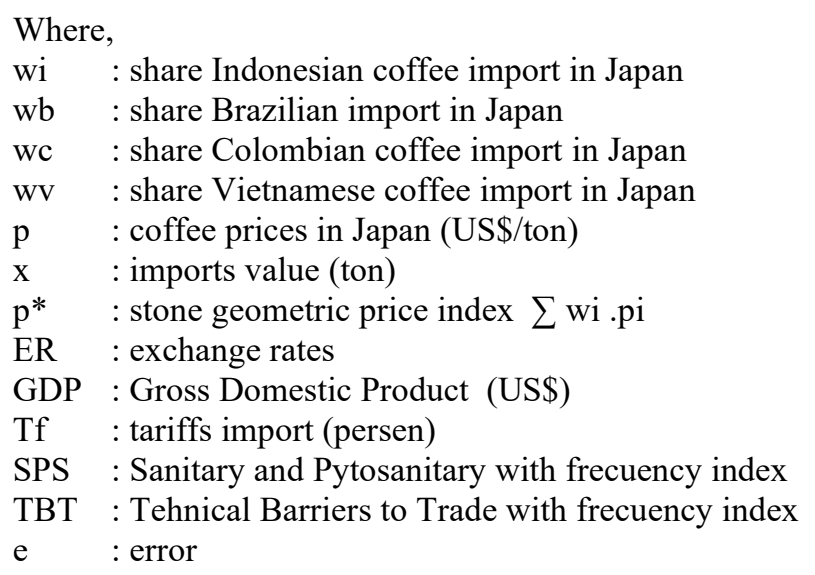

The geometric index of stone prices can affect the nature of the calculation of the AIDS model because it is not invariant to changes in the measurement unit [19]. For this reason, this research using a corrected stone price index that uses the log-linear Laspeyres index as follows (2).

$$
\begin{gathered}
\ln \mathrm{P}^{*}=\sum_{(\mathrm{i}=1)} S_{\mathrm{i}} \ln P_{i t} / P_{\mathrm{t}}^{0}(2) \\
\text { where, } P^{0}{ }_{\mathrm{t}}=\text { price in the based year }
\end{gathered}
$$

The non-tariff policy dummy variables (SPS and TBT) was done by using inventory approach with frequency index. The frequency index could be used to measure the presence or absence of non-tariff barriers and summarize the percentage of products where one or more policies are implemented [20]. This calculation can be formulated in equation (3).

Where,

$$
\mathrm{F}_{i j t}=\left[\sum\left(\mathrm{D}_{\mathrm{kt}} \mathrm{x} \mathrm{Mkt}\right)\right] /\left[\left(\sum \mathrm{Mkt}\right)\right] \times 100
$$

$\mathrm{F}_{i j t} \quad$ : frequency index exporters $\mathrm{i}$ to importer $\mathrm{j}$ at $\mathrm{t}$ year (percent)

$\mathrm{D}_{k t} \quad$ : dummy variables that showed the non tariff policies on $\mathrm{k}$ product at $\mathrm{t}$ year

$\mathrm{M}_{k t} \quad$ : product quantity of $\mathrm{k}$ with total of years from import quantities

The LA/AIDS equations were also restructured using constraints of homogenity and symmetry. The adding up nature itself had been fulfilled by itself in the model which was one of the advantages of the LA/AIDS model. From the AIDS parameters that have been estimated the value of the elasticities is determined (uncompensated elasticities) or Marshallian. The elasticity value was calculated to describe the level of competition between the four exporting countries, include Indonesia. The elasticity values were: (4) uncompensated own price elasticity, (5) uncompensated cross price elasticity, and (6) expenditure elasticity. These elasticities are calculated based on the formula as follows:

$$
\begin{gathered}
e_{i j}=\left[\left(\hat{y}_{i j}-\beta_{i} w_{i}\right) / \dot{w}_{i}\right]-1 \\
e_{i j}=\left[\left(\hat{y}_{i j}-\beta_{i} w_{j}\right) / \dot{w}_{i}\right] ; i \neq j \\
\eta_{i}=1+\beta i / \dot{w}
\end{gathered}
$$

where, $\hat{y}_{i j}$ represents price of good $\mathrm{i}$ in market $\mathrm{j}$

$\beta_{i}$ represents value of good i

$w_{i}$ represents share of good $\mathrm{i}$

$w_{j}$ represents share of good $\mathrm{j}$ 
Many AIDS model studies have been carried out both in Indonesia [14,15,21,22] and abroad [23-29]. The AIDS model is a more reliable model because it is based on the proportion (share) of the budget which is a linear function of the log of total income. This accommodates all obstacles such as additivity, homogeneity and symmetry that can be tested with statistics. Based on the AIDS model, the price is a bridge that connects the demand and supply sides.

From some of the above explanations regarding the AIDS model, the AIDS model has been widely used as a research analysis tool that is generally used to estimate the parameters of research. This is due to its advantages where the AIDS model can analyse expenditure elasticity, price elasticity and cross elasticity. The AIDS model can be used to analyse both micro and macro demand. Micro research to estimate simultaneous demand from various types of commodities at the consumer level. For macro use, the AIDS model is generally used to analyse international trade. So that in this study, the linear AIDS method can be used to answer what factors influence the demand for Indonesian coffee and how the influence of tariff and non-tariff policies on the elasticity of demand for Indonesian coffee which was modified by effect of trade barrier variables.

\section{Result and Discussions}

\subsection{The Dynamic of Trade Policy in Indonesian Coffee Export}

Trade policies which consist of tariff and non-tariff policies fluctuated from year to year. Import tariffs were levies imposed on goods when they entered national borders. Import tariffs are usually associated with protectionism, economic policies that restrict trade between countries. Since 1947, many international trade negotiations or multilateral agreements had been carried out to reduce import tariffs. Until now, many trade tariffs had been eliminated, especially in this study the tariff for green bean coffee. However, some other products that require more protection still apply import tariffs on these goods, such as roasted coffee.

Because of the protection against roasted coffee is higher than green bean coffee, the import tariff for roasted coffee tends to be higher than the import tariff for green bean coffee. Among Germany, Japan, and the United States as the main importing countries, Germany and Japan still impose relatively high import tariffs for roasted coffee. In contrast to the United States, both of green bean and roasted coffee have imposed zero import tariff.

The import tariff for Indonesian roasted coffee in Germany was 0.112 percent (19961997), then dropped to 0.035 percent (1998-2000), after that, fell back to 0.026 percent. This tariff was relatively lower than tariff of roasted coffee in Japan, which was 0.1 percent. This percentage of import tariffs had been stagnant from 1996 to the present.

In addition to the trade tariff policy, Indonesian coffee also subjected to non-tariff policies or NTMs (Non Tariff Measures). Sanitary and Phytosanitary (SPS) and Technical Barrier to Trade (TBT) are non-tariff import policies that were mostly enforced in various sectors by WTO member countries, including for the coffee commodity. WTO regulations allow the application of SPS and TBT in a country based on important reasons related to protection, health and safety for humans, animals, plants, and the environment. In addition, this policy was also implemented to improve the quality, packaging, labeling and standards of a product.

The number of SPS and TBT imposed by importing countries was quite large, especially in developed countries. Details of non-tariff policies in each of the main importing countries were shown in Table 2. 
Table 2. The number of NTM applied to Indonesian coffee commodities in 1996-2017

\begin{tabular}{|l|c|c|c|c|c|c|}
\hline \multirow{2}{*}{$\begin{array}{c}\text { Importing } \\
\text { Countries }\end{array}$} & \multicolumn{3}{|c|}{ Green Bean Coffee } & \multicolumn{3}{c|}{ Roasted Coffee } \\
\cline { 2 - 7 } & SPS & TBT & Total & SPS & TBT & Total \\
\hline Germany & 1 & 0 & 1 & 1 & 0 & 1 \\
\hline Japan & $\mathbf{7 7}$ & 3 & $\mathbf{8 0}$ & 93 & 37 & 130 \\
\hline The United States & 11 & $\mathbf{5 7}$ & 68 & $\mathbf{2 9 6}$ & $\mathbf{1 8 3}$ & $\mathbf{4 7 9}$ \\
\hline Total & 89 & 60 & 149 & 390 & 220 & 610 \\
\hline
\end{tabular}

Resource: WTO (2019) processed

Japan imposed the most NTMs on green bean, while the United States was imposed on roasted coffee. Germany was an importing country that implements the least NTM policy, it because importing coffee in Germany was an important activity. It can be seen that Germany was not only the biggest coffee importer country, Germany was also a big coffee exporting country. Therefore, for the sake of trade needs, Germany was not too focused on trade policies including non-tariffs.

In general, the NTM policies implemented by developed countries were more stringent than those in developing countries. An increase in income and greater prosperity tends to increase food security so that the demand for food safety products will increase in developed countries. To maintain food safety, developed countries implemented stricter policies such as SPS and TBT.

\subsection{The Effects of Trade Policy}

Tariff and non-tariff policies affect demand for Indonesian coffee imports. The import tariff for coffee beans in Germany had had a negative effect (-0.02028). This means that if the rate for green bean import tariff in Germany increases by 1 percent, the proportion (share) of Indonesian green bean export to Germany will decrease by 0.02028 percent (ceteris paribus). However, unlike green bean, tariffs on roasted coffee had a positive effect on the import demand for Indonesian roasted coffee. So, when the import tariff in Germany is raised, the demand for Germany imports from Indonesia will also increase. This was because the Germany imports were not only from Indonesia. Several countries such as Brazil, Colombia and Vietnam were also exporting countries for Germany. So when import tariffs rise, Germany prefers to import roasted coffee from Indonesia. Following are the results of an analysis of the effect of tariffs, SPS and TBT on Indonesian coffee demand based on LA/AIDS result (Table 3).

Apart from tariff policies, non-tariff policies such as SPS and TBT also had some negative and positive effects. It can be concluded that the NTM policy necessarily not to be a barrier to the course of trade. The estimation results in this study indicate that the NTM policy has a positive effect on the value of Indonesian coffee exports to the main importer countries. The positive influence of NTM policy was consistent with previous researches $[15,27,30,31]$ which states that NTM policies help to improve one of the market failures, which was asymmetric information received by consumers regarding the quality of the imported products. Openness of information about products will increase consumer demand. 
Table 3. The Result of The AIDS Model for Indonesian Coffee

\begin{tabular}{|l|l|l|l|l|l|c|}
\hline \multirow{2}{*}{ Variabel } & \multicolumn{3}{|c|}{ Green Bean Coffee } & \multicolumn{3}{c|}{ Roasted Coffee } \\
\cline { 2 - 7 } & Germany & Japan & The US & Germany & Japan & The US \\
\hline$p_{\mathrm{i}}$ & $-0,07166^{*}$ & $-0,01367$ & $-0,05879^{* * *}$ & $-0,00016$ & 0,00386 & $-0,00213$ \\
\hline$p_{\mathrm{b}}$ & $-0,05964^{* *}$ & $-0,03327$ & $-0,01007$ & $0,00025^{*}$ & $-0,00102$ & $-0,00352$ \\
\hline$p_{\mathrm{c}}$ & 0,02745 & $-0,00683$ & $-0,10148^{* * *}$ & $-0,00009$ & $-0,00179$ & 0,00041 \\
\hline$p_{\mathrm{v}}$ & $0,11462^{* * *}$ & $0,04634^{* * *}$ & 0,00150 & $-0,00001$ & 0,00023 & 0,00067 \\
\hline$p_{\text {row }}$ & $-0,01077$ & 0,00743 & $0,16884^{* * *}$ & $-0,00192^{* * *}$ & $-0,00128$ & 0,00458 \\
\hline $\mathrm{x}$ & 0,05649 & $-0,00235$ & $-0,00157$ & $-0,00142^{* * *}$ & $-0,00421$ & $-0,00287$ \\
\hline GDP & $-0,20240^{* * *}$ & $-0,25095^{* * *}$ & $0,23182^{* *}$ & $-0,00031^{* *}$ & 0,01100 & 0,00905 \\
\hline ER & $-0,00015$ & $0,00825^{* *}$ & 0,01014 & $-0,03783^{*}$ & $0,01429^{* * *}$ & 0,00123 \\
\hline Tariffs & $-0,02028^{*}$ & - & - & $0,00578^{* *}$ & $0,01960^{* * *}$ & - \\
\hline$F_{\mathrm{i}}$ SPS & $-0,49772^{*}$ & 0,09389 & 0,03721 & $-0,01607^{* * *}$ & $-0,13958^{* *}$ & $-0,02164$ \\
\hline$F_{\mathrm{i}}$ TBT & - & $-0,15343$ & $-0,07305$ & - & $-0,01254$ & 0,02831 \\
\hline$R$-Square & $0,2120^{* * *}$ & $0,9330^{* * *}$ & $0,4208^{* * *}$ & $0,8798^{* * *}$ & $0,9435^{* * *}$ & 0,4775 \\
\hline
\end{tabular}

Note: ${ }^{*}$ sig. 1 percent $\left.(0,01),{ }^{* *}\right)$ sig. 5 percent $(0,05),{ }^{* * *}$ sig. 10 percent $(0,10)$

\subsection{The Position of Indonesian Coffee Market Based on Demand System}

The position of Indonesian coffee was illustrated by calculating the demand elasticity based on the LA/AIDS model, where the tariff and non-tariff varibale were included in the model. Demand elasticity consists of own price elasticity, expenditure elasticity and cross price elasticity. Own price elasticity means the amount (as a percentage of total) that quantity demanded changes as price changes, and expenditure elasticity means the amount (as a percentage of total) that demand changes as expenditure changes. Both own price elasticity and expenditure elasticity showed by Table 4 .

Table 4. Own Price Elasticity and Expenditure Elasticity of Indonesian Green Bean and Roasted Cofee in Germany, Japan and The United States

\begin{tabular}{|l|c|c|c|c|}
\hline \multirow{2}{*}{ Importirs } & \multicolumn{2}{|c|}{ Green Bean Coffee } & \multicolumn{2}{c|}{ Roasted Coffee } \\
\cline { 2 - 5 } & $\begin{array}{c}\text { Own Price } \\
\text { Elasticity }\end{array}$ & $\begin{array}{c}\text { Expenditure } \\
\text { Elasticity }\end{array}$ & $\begin{array}{c}\text { Own Price } \\
\text { Elasticity }\end{array}$ & $\begin{array}{c}\text { Expenditure } \\
\text { Elasticity }\end{array}$ \\
\hline Germany & -2.76260 & 2.34487 & -1.37741 & -2.34617 \\
\hline Japan & -1.13542 & 0.97628 & -0.82235 & 0.81093 \\
\hline The US & -2.00980 & 0.97291 & -3.18260 & -1.94687 \\
\hline
\end{tabular}

The estimation elasticities resulted that all own price elasticities, both of green bean and roasted coffee, had a negative sign which was consistent to microeconomic theory of a downward slope demand curve. The own price elasticity of green beans in Germany, Japan, and The United States were $-2.76260,-1.13542,-2.00980$ respectively, meaning that when there is an increase in the price of green beans from Indonesia by 1 percent, it will reduce the demand for imported Indonesian green beans by 2.76260 percent in Germany, 1.13542 percent in Japan, and 2.00980 in The United States. The elasticity of Indonesian green bean in those countries were more than one, meaning that Indonesian coffee beans in those all countries had a price sensitivity level or elastic, where Germany was the highest. 
Then, the own price elasticities of roasted coffee in Germany, Japan and The United States respectively were $-1.37741,-0.82235$, and -3.18260 , where the highest elasticity of Indonesian roasted coffee was in The United States and the lowest elasticity was in Japan. The own price elasticity in Japan was less than one, meaning that Indonesian roasted coffee in Japan had a los price sensitivity level or inelastic. So that, the high import tariffs in Japan did not make the high impact to the Indonesian roasted coffee export because the increase price, the decrease Indonesian roasted coffee export not very high. Contrast to the roasted coffee in The United States, despite the zero import tariffs, the price sensitivity level of Indonesian roasted coffee in The United States was very high, reached to tripled.

Expenditure elasticity showed the percentage change in the coffee consumption for a percentage change in expenditure. Table 4 results that if the expenditure elasticity greater than 1 , it indicates that the product is a luxury good. For example, Indonesian green bean coffee in Germany was 2.34487. It means that, the demand for green bean in Germany increase by 2.34487 percent when the expenditure increase by 1 percent. In other words, a higher proportion of budget is spent on Indonesian green bean as the consumer in Germany gets richer.

Then, if the expenditure elasticity less than 1, it implies that the product is necessity. Both Indonesian green bean and roasted coffee were inelastic, it means that coffee was necessary goods in Japan. This result was in the same line with some of the previous work that coffee and coffee beverage were necessities in Japan [24]. Moreover, another research using LA/QUAIDS showed that the model found expenditure price elasticity for coffee to be inelastic.

However, this result contradicts to the expenditure elasticities of roasted coffee in Germany and The United States. Because of negative expenditure elasticities for Indonesian roasted coffee in both countries (-2.34617 and -1.94687), an increase in expenditure for roasted coffee in Germany by 1 percent, it will reduce demand for Indonesian roasted coffee by 2.34617 percent and an increase in expenditure for roasted coffee in The United States by 1 percent, it will reduce demand for Indonesian roasted coffee by 1.94687 percent. Roasted coffee in both countries was an inferior good. It means that demand for the good falls as income rises.

Beside own price elasticity and expenditure elasticity, there was also cross price elasticity. It showed the amount (as a percentage of total) that demand for a good change as price of another good change. A negative sign indicates a substitution relationship while a negative sign indicates a complementary relationship. The result of demand elasticity of Indonesian green bean and roasted coffee are illustrated in Table 5, Table 6 and Table 7.

Table 5. Cross Price Elasticity of Indonesian Green Bean and Roasted Cofee in Germany

\begin{tabular}{|l|c|c|c|c|c|c|c|c|}
\hline \multirow{2}{*}{ Price } & \multicolumn{4}{|c|}{ Green Bean } & \multicolumn{4}{c|}{ Roasted Coffee } \\
\cline { 2 - 9 } & Ind. & Brazil & Col. & Viet. & Ind. & Brazil & Col. & Viet. \\
\hline Indonesia & - & $-1,80376$ & 0,51235 & 2,58287 & - & 0,60775 & $-0,19322$ & $-0,01707$ \\
\hline Brazil & $-0,26765$ & - & 0,03361 & $-0,50071$ & 0,09908 & - & $-0,10188$ & 0,06058 \\
\hline Colombia & 0,36447 & 1,18987 & - & 0,19976 & $-0,03012$ & $-0,09828$ & - & 0,00736 \\
\hline Vietnam & 1,01395 & $-1,19630$ & $-0,16732$ & - & 0,05736 & 1,20876 & 0,16268 & - \\
\hline
\end{tabular}

Table 5 showed that Brazilian and Indonesian green beans coffee were complementary $(-0,26765)$, but Colombian and Vietnamese green beans substitute with Indonesian green bean coffee $(0,36447$ and 1,01395). This means that 1 percent increase in the price of Brazilian green bean will decrease demand for Indonesian green bean by 0,26765 percent, while 1 percent increase in the price of Colombian and Vietnamese green beans will increase demand for Indonesian green bean by 0,36447 percent and 1,01395 percent. The 
cross price elasticity for Indonesian and Colombian roasted coffee had negative signs, which indicated that these pairwise products were complementary. Similarly, the cross price elasticity for Brazilian-Indonesian roasted coffee and Vietnamese-Indonesian roasted coffee was positive, which implies that Indonesian roasted coffee was a substitute for Brazilian and Vietnamese coffee.

Table 6 which showed the cross price elasticity of Indonesian coffee in Japan also had a positive and negative signs. Both green bean and roasted coffee, Indonesia with Brazil and Colombia were complementary, but Indonesia with Vietnam substitute each other.

Table 6. Cross Price Elasticity of Indonesian Green Bean and Roasted Cofee in Japan

\begin{tabular}{|l|c|c|c|c|c|c|c|c|}
\hline \multirow{2}{*}{ Price } & \multicolumn{4}{|c|}{ Green Bean } & \multicolumn{4}{c|}{ Roasted Coffee } \\
\cline { 2 - 9 } & Ind. & Brazil & Col. & Viet. & Ind. & Brazil & Col. & Viet. \\
\hline Indonesia & - & $-0,32892$ & $-0,06362$ & 0,46868 & - & $-0,03405$ & $-0,07279$ & 0,01163 \\
\hline Brazil & $-0,13906$ & - & $-0,11270$ & $-0,15991$ & $-0,01693$ & - & $-0,04851$ & 0,05738 \\
\hline Colombia & $-0,09813$ & $-0,27809$ & - & $-0,03927$ & $-0,04092$ & $-0,06291$ & - & 0,11141 \\
\hline Vietnam & 0,81187 & $-0,25077$ & 0,29866 & - & 0,06559 & 0,56916 & 0,64405 & - \\
\hline
\end{tabular}

The Cross price elasticity of Brazilian-Indonesian green bean and roasted coffee respectively were $-0,13906$ and $-0,01693$. This means that 1 percent increase in the price of Brazilian green bean will decrease demand for Indonesian green bean by $-0,13906$ percent and decrease demand for Indonesian roasted coffee by $-0,01693$ percent. It also happened to Colombian-Indonesian either green bean or roasted coffee. On the other hand, because of Indonesian coffee was substitute for Vietnamese coffee, so when 1 percent increase in the price of Vietnamese green bean will increase demand for Indonesian green bean by 0,81187 percent and increase demand for Indonesian roasted coffee by 0,06559 percent.

Then, table 7 showed the cross price elasticity of Indonesian coffee in The United States. Either Indonesian-Brazilian green beans or roasted coffee and IndonesianColombian green beans were complementary. The others, Indonesian green bean substitute for Vietnamese green bean coffee and Indonesian roasted coffee substitute for Colombian and Vietnamese roasted coffee.

Table 7. Cross Price Elasticity of Indonesian Green Bean and Roasted Cofee in The United States

\begin{tabular}{|l|c|c|c|c|c|c|c|c|}
\hline \multirow{2}{*}{ Price } & \multicolumn{4}{|c|}{ Green Bean } & \multicolumn{4}{c|}{ Roasted Coffee } \\
\cline { 2 - 10 } & Ind. & Brazil & Col. & Viet. & Ind. & Brazil & Col. & Viet. \\
\hline Indonesia & - & $-0,16771$ & $-1,74015$ & 0,02779 & - & $-3,52627$ & 0,56250 & 0,70470 \\
\hline Brazil & $-0,05783$ & - & 0,22446 & $-0,15764$ & $-0,11111$ & - & 1,35535 & 0,25168 \\
\hline Colombia & $-0,49031$ & 0,22070 & - & 0,06054 & 0,00821 & 0,73105 & - & $-0,02176$ \\
\hline Vietnam & 0,02593 & $-0,37994$ & 0,21826 & - & 0,11888 & 1,28647 & $-0,13763$ & - \\
\hline
\end{tabular}

Table 5, table 6 and table 7 showed that Indonesian coffee substitute for Vietnamese coffee both green beans and roasted coffee, but it complementary with Colombia and Brazilian coffee in almost importing countries (Germany, Japan and The United States). That was indicates that Indonesia was a competitor to Vietnam. Those, had been summarized in Table 8. 
Table 8. Summary Result of Cross Price Elasticity

\begin{tabular}{|l|c|c|c|c|c|c|}
\hline \multirow{2}{*}{ Countries } & \multicolumn{3}{|c|}{ Green Bean } & \multicolumn{3}{c|}{ Roasted Coffee } \\
\cline { 2 - 7 } & Germany & Japan & The US & Germany & Japan & The US \\
\hline $\begin{array}{l}\text { Indonesia- } \\
\text { Brazil }\end{array}$ & Complement & Complement & Complement & Substitute & Complement & Complement \\
\hline $\begin{array}{l}\text { Indonesia- } \\
\text { Colombia }\end{array}$ & Substitute & Complement & Complement & Complement & Complement & Substitute \\
\hline $\begin{array}{l}\text { Indonesia- } \\
\text { Vietnam }\end{array}$ & Substitute & Substitute & Substitute & Substitute & Substitute & Substitute \\
\hline
\end{tabular}

Based on the findings of the study, in order to improve the market share of Indonesian coffee, these following policy implications should be addressed: (1) Japan should be a main target for Indonesian coffee export. Although the import tariffs in Japan was the highest than others, but coffee was not sensitive with the price changes and it was a necessity there. (2) Indonesia should be established premium export coffee product. This could explain why the expenditure elasticity of Indonesian coffee was elastic, even the negatives expenditure elasticity. It implies that consumers in the major importing countries seemed to lose confidence in Indonesian coffee, especially for roasted coffee. Therefore, understanding the preference of the market and maintaining the quality standards of coffee in the main importing market has to be given considerable attention to maintain and/or improve the market share and competitiveness of Indonesian coffee.

\section{Conclusion}

The empirical results concluded that the variable tariffs and non-tariffs as the trade policies effect to demand of Indonesian coffee export, either negative or positive. More protection required on a product, more tariff and non-tariffs will be applied. So that, roasted coffee which require more protection had been applied more import tariffs and non-tariffs than green beans coffee.

Related to demand elasticity, Indonesian green bean was found to be elastic in Germany, Japan, and The United States. Then, Indonesian roasted coffee was found to be inelastic in Japan. Indonesian green bean was a luxury good only in Germany, but Indonesian roasted coffee was an inferior good in Germany and The United States. Both Indonesian green bean and roasted coffee were a necessity in Japan. Almost Indonesian coffee substitute for Brazilian coffee and Colombian coffee, and complementary with Vietnamese coffee as its competitor.

\section{References}

1. I. E. Institute, (UNIED), and University Network For Indonesia Export Development, Superior Commodity, February 2 (Indonesia Eximbank, Jakarta, 2019).

2. Center for Agricultural Data and Information Systems, 116 (2016).

3. ICO, Int. Coffee Organ. 7 (2020).

4. Baroh, N. Hanani, B. Setiawan, and D. Koestiono, Int. J. Agric. Innov. Res. 3, 2319 (2014).

5. Ministry of Agriculture, Strategic Plan of the Ministry of Agriculture for 2015-2019, 2015th ed. (Ministry of Agriculture, n.d.).

6. F. Achmad, National Coffee Processing Industry Development Policy, 2015th ed. (Ministry of Industry, n.d.). 
7. United Nations International Trade Statistics Database (UN COMTRADE), Value, Price and Quantity Export of Indonesian, Brazilian, Colombian and Vietnamese Coffee in Japan 1996-2017 (2019).

8. Worldbank, Exchange Rates and Gross Domestic Product (2019).

9. International Trade Center (ITC), Import Tariffs 1996-2017 (2019).

10. World Trade Organization (WTO), Non-Tariff Measures: Sanitary \& Phytosanitary and Technical Barier to Trade (2019).

11. E. J.M. and G. L.A., Appl. Econ. 35, 1025 (2003).

12. J. M. Eakins and L. A. Gallagher, Appl. Econ. 35, 1025 (2003).

13. F. Virgantari, Analysis of Demand for Fishery Products in Indonesia: A CrossSectional Study, Bogor Agricultural University, 2012.

14. A. S. Jamil, Demand Analysis of Indonesian Salt Import, Bogor Agricultural University, 2015.

15. M. R. Syaffendi, A. Rifin, and S. Jahroh, J. Agribisnis Indones. 1, 125 (2013).

16. A. Rifin, Int. J. Trade, Econ. Financ. 4, 279 (2013).

17. Y. Wan, C. Sun, and D. L. Grebner, J. Agric. Appl. Econ. 42, 643 (2010).

18. R. F. Engle and C. W. J. Granger, Appl. Econom. 39, 107 (1987).

19. G. Moschini, Agric. Appl. Econ. Assoc. 42, 767 (1995).

20. M. Fugazza, Policy Issues Int. Trade Commod. Study Ser. 57, 1 (2013).

21. T. Suherman, Analysis of Indonesia's Palm Oil Import Demand in Europe 4, Bogor Agricultural University, 2016.

22. A. R. Simanjuntak, Demand for Indonesian Plywood in the Japanese Market with Almost Ideal Demand System (AIDS) Approach, Bogor Agricultural University, 2017.

23. W. Gebrehiwot and A. Daloonpate, Kasetsart J. - Soc. Sci. 33, 142 (2012).

24. M. F. Yohannes and T. Matsuda, Beta Work. Pap. 354, 26p. (2011).

25. M.-H. Li and K.-O. Jung, J. Korea Acad. Coop. Soc. 15, 72 (2014).

26. I. Galarraga and A. Markandya, Econ. Agrar. y Recur. Nat. 4, 109 (2004).

27. F. M. De Almeida, F. M. M. Gomes, and O. Monteiro da Silva, Int. Assoc. Agric. Econ. Trienn. Conf. (2012).

28. A. P. A., C. J. O., and W. X, Int. J. Soc. Sci. Manag. 3, 38 (2016).

29. F. Abaunza Osorio, 27th Int. Conf. Syst. Dyn. Soc. 1 (2009).

30. R. D. Handoyo, A. Erlando, R. D. R. Sari, F. D. Riyanto, and A. P. Darmawan, Adv. Econ. Bus. Manag. Res. 101, 236 (2019).

31. K. Sarirahayu and A. Aprianingsih, Asian J. Technol. Manag. 11, 1 (2018). 